\title{
Pancreas transplant in type 1 diabetes mellitus: the emerging role of islet cell transplant
}

\section{Inderpal Singh Kochar, Rakhi Jain}

Department of Pediatric and Adolescent Endocrinology, Indraprastha Apollo Hospital, New Delhi, India
See the commentary "Islet cell transplantation transitioning to proven therapy for type 1 diabetes" via https://doi.org/10.6065/apem. 2121006 edi02.

Received: 18 December, 2020

Revised: 22 February, 2021

Accepted: 12 May, 2021

Address for correspondence:

Rakhi Jain

Department of Pediatric and Adolescent Endocrinology, Indraprastha Apollo Hospital, Sarita Vihar, New Delhi 110076, India

Email: drrakhi09@gmail.com

https://orcid.org/0000-0002-1935$308 \mathrm{X}$
Pancreas transplant, both whole pancreas and islet cell, is a known therapeutic option for treatment of type 1 diabetes mellitus. Islet cell transplant began as an experimental therapy but is emerging to be quite beneficial due to less surgical risk and fewer complications. It is also considered a promising option in pediatric patients. In this review the authors discuss the indications, procedure, and benefits of islet cell transplant along with newer strategies for improving outcomes.

Keywords: Pancreas transplant, Islet cell, Type 1 diabetes, Pediatric diabetes, Hypoglycemia

\section{Highlights}

This article highlights the indications,procedure and outcome of islet transplant .It discusses the pros and cons of the procedure to evaluate how it fares as a treatment modality in type 1 Diabetes in the current era, with a brief insight into its outcome in pediatric patients.

\section{Introduction}

Type 1 diabetes mellitus (T1DM) is an emerging noncommunicable disease, both in India and abroad. It occurs due to the autoimmune destruction of insulin secreting beta cells of the pancreas. ${ }^{1)}$ It is associated with both short-term problems of hypoglycemia, hyperglycemia, ketoacidosis, and long-term complications such as nephropathy and retinopathy, among others. The best available medical strategy for achieving normoglycemia is subcutaneous insulin. A basal bolus regimen is currently the most favored approach to keep blood sugar levels in control. Glycemic control is assessed on the basis of glycosylated hemoglobin (HbA1c) levels. Transplant, either whole pancreas or islet cell, is a known therapeutic option for treatment of type 1 diabetes in adults. Initiated as an experimental therapy in the 1980s, pancreatic transplant has been reinvented with timely advances in adult care and is now a commonly performed procedure. ${ }^{2)}$

For a child with T1DM, multiple daily injections of insulin and repeated pricks to check blood sugar as a part of self-monitoring of blood glucose makes life difficult for the patient and the family. The not-so-rigid meal timings of children, their resistance to pricks, parental anxiety, and the risk of hypoglycemia have all indicated the need for a treatment modality that is independent of insulin. Besides, the recommended target $\mathrm{HbAlc}$ of $<7 \%$ is difficult to achieve and the need for stringent blood sugar control poses the risk of hypoglycemia, which is detrimental to the growing brain of the child. ${ }^{3)}$ Thus, there is increasing interest in the role of pancreatic and islet transplant in T1DM.

\section{Categories of transplant (whole pancreas)}

Broadly, pancreas transplant consists of three types. ${ }^{4)}$ 


\section{Simultaneous pancreas-kidney transplant}

This is most commonly performed and comprises nearly $70 \%$ of cases. It is usually carried out in cases of T1DM with advanced chronic kidney disease due to diabetic nephropathy.

\section{Pancreas after kidney transplant}

This is done in $20 \%$ of cases, often after living donor renal transplant or previous simultaneous pancreas-kidney where allograft has failed.

\section{Pancreas transplant alone}

Uncommonly performed, this is done in $10 \%$ of type 1 diabetics when renal function is preserved but glycemic control is poor and repeated episodes of hypoglycemia have led to hypoglycemic unawareness. These patients may be struggling with numerous issues leading to noncompliance with insulin therapy.

The results of pancreatic transplant have improved over the years and provide good glycemic control, however, it is an invasive procedure. ${ }^{5}$ Although pancreas transplant is the gold standard, the advent of islet cell transplant has emerged as a promising solution providing insulin independence with normalization of glycated hemoglobin and minimal surgical risk (Table 1). ${ }^{6}$

Whole pancreas transplant has been a common procedure in adult diabetics but rare in pediatric patients. The probable reasons behind this seem to be that (1) nephropathy and other chronic complications of diabetes are rare in younger patients; (2) intensive insulin therapy is always prioritized by both the clinician and parents over surgical risk; and (3) there were technical hurdles in transplant surgery for the pediatric age group including donor, recipient, and graft rejection issues. Hence, the advent of islet cell transplant appeared to be a promising option as it is not a complex surgical procedure, needs a shorter course of immunosuppression and provides better glycemic control, although it is still under evaluation for long-term results.

\section{Islet cell transplant}

\section{History}

From a historical perspective, in 1972 islet cell transplant was first an experiment where islet cell isograft reversed streptozocine-induced diabetes in rats. ${ }^{7}$ In the 1980s, autologous islet cell transplant performed for chronic pancreatitis showed that it was able to maintain long-term normoglycemia. Ricordi et al. ${ }^{8)}$ achieved a breakthrough when they demonstrated that the pancreas could be digested using collagenase, and islets could be separated. Over the years, with the development of the Edmonton protocol for islet preparation and posttransplant treatment, including glucocorticoid free immunosuppressive therapy, the procedure evolved to show insulin independence up to $60 \%-90 \%$ in various studies. ${ }^{6.9-11)}$

\section{Indications}

Table 2 shows the common indications of islet transplant. ${ }^{11,12)}$

\section{Donor}

Pancreas donor characteristics associated with successful isolation of islet cells include:

- Age between 20 years and 50 years body mass index $>25 \mathrm{~kg} / \mathrm{m}^{2}$ and $\leq 30 \mathrm{~kg} / \mathrm{m}^{2}{ }^{13-15)} \mathrm{HbAlc}<6.5 \%$ and normal blood glucose levels at the time of organ donation.

- Warm ischemia $<30$ minutes and cold ischemia $<4$ hours (in case of deceased cardiac donors) ${ }^{16-19)}$

\section{The procedure}

A pancreas is recovered from a deceased or brain-dead donor

Table 1. Important comparisons of pancreas and islet transplantation ${ }^{5,6)}$

\begin{tabular}{lll}
\hline Points to differentiate & \multicolumn{1}{c}{ Pancreas transplantation } & \multicolumn{1}{c}{ Islet transplantation } \\
\hline Type & Whole organ transplant & Islet cell transplant alone \\
Indication in diabetes & Complications of type 1 diabetes & Used instead of pancreas transplant in some patients \\
Indication in chronic pancreatitis & No specific indication & As part of total pancreatectomy and autologous islet transplantation \\
Pediatric indication & No routine indication & Part of total pancreatectomy and autologous islet transplant \\
Insulin independence rates & $70 \%$ at $5 \mathrm{yr}$ & $25 \%-50 \%$ at $5 \mathrm{yr}$ \\
Surgical risk & More & Less \\
Complications & More & Less \\
\hline
\end{tabular}

\section{Table 2. Common indications of islet transplant ${ }^{11,12)}$}

1. Type 1 diabetes mellitus of $>5$ yr duration with negative C-peptide (fasting and or/stimulated)

2. Type 1 diabetes complicated by episodes of severe hypoglycemia associated with hypoglycemia unawareness and poor glycemic control despite compliant intensive insulin therapy

3. Cystic fibrosis related diabetes

4. Diabetes associated with chronic pancreatitis and following pancreatectomy 
by meticulous surgery and transported to the islet isolation center in University of Wisconsin in solution for intracellular preservation. ${ }^{20,21)}$ The pancreatic duct is cannulated and active collagenase enzyme is delivered to the islet-acinar interface to extract the islet cells. ${ }^{22}$

The above process was revolutionized by Ricordi's automated method, which used a chamber to free the islets. ${ }^{23)}$ After digestion, multiple washings and recombinant steps, this islet extract is maintained in culture for 24-72 hours before release and clinical transplantation. This improves purification, as contaminated exocrine tissue does not survive well in culture.

Although $10 \%-20 \%$ of the islet mass is lost during culture, the final product has a reduced state of inflammation that decreases immune response, both innate and adaptive. The final product should meet the criteria for safety, purity, potency, and identity. ${ }^{2324)}$ The recipient is started with intensive insulin therapy perioperatively to maintain normoglycemia along with induction and maintenance of immunosuppressive therapy. Intraportal transplant of islet cell may be accomplished via a percutaneous transhepatic route or by open surgery with the former being preferred due to low surgical risk. Percutaneous intraportal islet transplantation is done under fluoroscopic or ultrasonographic guidance or a combination of both, such as the Edmonston group. ${ }^{21)}$ The final islet product, suspended in $250 \mathrm{~mL}$ of transplant media in an infusion bag, is loaded with heparin (70 units/kg recipient weight) and infused under gravity after confirming the position of the catheter tip by portal venogram. ${ }^{25)}$

\section{Outcomes of islet transplant (Table 3) and its metabolic benefits}

The Collaborative Islet Transplant Registry report of 2014 has shown notably improved outcomes, both short- and longterm, with achievement of insulin independence in up to $80 \%$ of patients with favorable factors such as autoantibody negative for islet antigen, islet mass $>5,000$ islet equivalents (IEQ) $/ \mathrm{kg}$, among others. ${ }^{23,26,27)}$ The minimal beta cell mass for a significant effect after transplant is greater than 5,000 IEQ per $\mathrm{kg}$ of the recipient body weight. ${ }^{28)}$ Some centers claim to have insulin independence rates of $50 \%-70 \%$ by five years after the transplantation approaching those of patients of type 1 diabetes with whole pancreas transplant. ${ }^{29-31)}$

Studies have revealed that endogenous insulin secretion from transplanted islets led to near normalization of blood glucose. It also resulted in decreased basal hepatic glucose output and normal plasma amino acid levels. Transplant restores glucagon secretion, normalization of hepatic glucose production, and improvement in lipid profile and insulin mediated protein kinetics. Clinical benefits seen are numerous and significant (Table 4). Well controlled HbAlc levels were seen after transplant in patients off insulin, although insulin independence seemed to decrease over a period of time. Even with intensive blood glucose monitoring, no other insulin regimen can achieve such goals. ${ }^{32)}$ The success of pancreas and islet transplant in treating severe hypoglycemia led to its being recommended as a therapeutic option in cases of problematic hypoglycemia. ${ }^{33)}$

Table 3. Outcome of islet transplant

\begin{tabular}{|c|c|c|c|}
\hline Study & Subjects & Insulin dependence at 1 year & Year \\
\hline Ryan et al. ${ }^{40)}$ & Adult $(n=65)$ & $68 \%$ & 2005 \\
\hline Trial by Immune Tolerance Network ${ }^{28)}$ & Adult $(n=36)$ & $44 \%$ & 2006 \\
\hline Bellin et al. ${ }^{34)}$ & Pediatric $(n=24)$ & $78 \%$ & 2008 \\
\hline Japanese Trial of Islet Transplantation ${ }^{41)}$ & Adult $(n=18)$ & $17 \%$ & 2009 \\
\hline Sutherland et al. ${ }^{12)}$ & Adult and Pediatric $(n=409)$ & $30 \%$ at $3 \mathrm{yr}$ ( $25 \%$ in adults, $55 \%$ in children) & 2012 \\
\hline Chinnakotla et al. ${ }^{35)}$ & Pediatric $(n=75)$ & $\begin{array}{l}\text { 41.3\% ( } 31 \text { of } 75 \text { ) achieved insulin independence. } 28 \text { of } 31 \\
\text { patients achieved insulin independence within } 1 \text { year. }\end{array}$ & 2014 \\
\hline Johnston et al. ${ }^{42)}$ & Adult $(n=36)$ & $33.3 \%$ & 2015 \\
\hline Hering et al. $^{43)}$ & Adult $(n=48)$ & $52.1 \%$ & 2016 \\
\hline CITR annual report ${ }^{44)}$ & Adult and pediatric $(n=877)$ & $50 \%$ & 2015 \\
\hline Bellin et al. ${ }^{45)}$ & Pediatric $(n=17)$ & $82 \%$ & 2017 \\
\hline Kirstie et al. ${ }^{46)}$ & Adult & $60 \%$ & 2020 \\
\hline
\end{tabular}

CITR, Collaborative Islet Transplant Registry.

Table 4. Pros and cons of islet cell transplant ${ }^{11,14,32,33,39)}$

\begin{tabular}{ll}
\hline Pros & \multicolumn{1}{c}{ Cons } \\
\hline Improved quality of life & Low donor availability \\
Prevention of recurrent diabetic nephropathy & Process of islet isolation and purification is tedious with low yield \\
Freedom of exogenous insulin with normal glucose & Risks associated with immunosuppression \\
Marked reduction in episodes of hypoglycemia & Procedure requires expertise \\
Normalization of glycosylated hemoglobin & Risk of routine operative risk \\
Less stringent dietary restrictions & Expensive \\
Less frequent blood glucose monitoring & Less long-term data on safety and outcome \\
Stabilization of or reduced secondary complications & Still not the standard recommended procedure for treatment of type 1 diabetes mellitus \\
\hline
\end{tabular}


Reduced frequency of blood glucose monitoring and freedom from insulin injection is a huge benefit in the pediatric population, as frequent pricks can be frightening for them.

\section{Pediatric outcomes}

Pancreas and islet transplant is uncommon in children with diabetes due to the reasons enumerated above. Hence the experience in pediatrics is limited. Islet cell transplant was tried and considered better than whole pancreas transplant, which poses major operative risks. Other disadvantages of the latter include chronic immunosuppression and its related side effects and posttransplant complications. Islet transplant in the pediatric age group has been conducted mostly for chronic pancreatitis after total pancreatectomy where improvement in pain resolution and quality-of-life were comparable to adults, with $>80 \%$ of recipients being able to attend school or work. ${ }^{34)}$ Rates of insulin independence were seen up to $40 \%$ at two years post islet transplant in these children. More than $50 \%$ of the youngest recipients between five and 12 years of age were insulin-independent at 1 year post islet transplant. During three years of follow-up in pediatric patients, $\mathrm{HbAlc}<7.0 \%$ was maintained in $100 \%$ who received $>5,000 \mathrm{IE} / \mathrm{kg} .{ }^{11,35)}$ So younger age and shorter duration of pancreatitis have been associated with higher islet yields, as in adults. ${ }^{36)}$

Avoiding a major operative procedure and opting for a less invasive islet cell transfer therapy is quite alluring but it needs to be poised against the scarcity of donors and difficulties faced in processing the islet cells. Besides, there is a lack of equipment and expertise in successful performance of such complex procedures. In pediatric ages, especially when development of complications due to diabetes is not imminent in the near future, the balance between the efficacy and toxicity of the procedure needs to be evaluated. As there is little experience of islet cell transplant in the pediatric age group, long-term studies are needed to evaluate the outcome of transplant in cases in chronic pancreatitis in children. Even more experience is needed for such procedures in children with T1DM, and their outcome on follow-up needs to be studied. Only then can better insight be available about the future of such a procedure in the pediatric age group.

\section{Technological advances}

Newer developments in transplant procedures have made it possible, to some extent, to overcome existing barriers such as scarcity of donors and immune reactions leading to rejection. Porcine islet cells have been used to form xenoislets for transplantation, but immune rejection was a drawback. Extensive studies are being carried out to investigate the ability of human embryonic stem cells and induced pleuripotent stem cells to differentiate into functional insulin producing cells. This may lead to successful use of such cells for transplant. ${ }^{37)}$

To protect against immune reactions, islet encapsulation is another advanced method of islet transplantation. Isolated islets of human origin or porcine xenoislets are encapsulated in a semipermeable membrane that allows the passage of nutrients and hormones but prevents cell contact with immune cells and hence, protects against immune reactions. This can be particularly beneficial for xenotransplantation. ${ }^{38)}$ When multiple islets are encapsulated within a device $>1 \mathrm{~mm}$ in diameter, it is called macroencapsulation. It is usually placed in an extravascular space. Microencapsulation means coating of islets in an immunoprotective cover.

Several innovative drugs are being tried to limit reduction of transplanted islet cell mass in the posttransplant period. Efforts are being made to improve the efficacy of islet graft with the minimal toxicity of immunosuppressive therapy. Several methods to reverse diabetes with cellular replacement of insulin secreting cells, along with ways to prevent recurrent autoimmune destruction of the newly transplanted cells, are under study.

\section{Conclusion}

Diabetes mellitus is a chronic debilitating disease associated with macrovascular and microvascular complications. Maintaining euglycemia is crucial to preventing complications and also reversing their progression. Currently, intensive insulin regimes have contributed to maintenance of normal blood glucose levels, which is an uphill task, and more so in the pediatric population. Emergence of islet transplant as an experimental procedure and its evolution over the last 2 to 3 decades has opened new avenues in the treatment of T1DM. A great deal of research and experiments in islet transplant are evolving to provide a novel strategy for providing successful normalization of $\mathrm{HbAlc}$ with insulin independence. Its lower surgical risk, and the reduced toxicity of immune therapy with lower risk of complications makes it an ideal future prospect of treatment in the pediatric age group. The major limiting factor in transplant success is the wide gorge between demand and supply due to organ shortage, however, new avenues of research have led to numerous developments that seem to overcome the existing barriers. Still, multicentric trials on follow-up of the transplant procedure are needed before recommending it as a routine therapeutic option for T1DM.

\section{Conflicts of interest}

No potential conflict of interest relevant to this article was reported.

\section{References}

1. Das AK. Type 1 diabetes in India: overall insights. Indian J Endocrinol Metab 2015;19(Suppl 1):S31-3.

2. Dholakia S, Oskrochi Y, Easton G, Papalois V. Advances in pancreas transplantation. J R Soc Med 2016;109:141-6.

3. Cryer PE. Hypoglycemia in type 1 diabetes mellitus. Endocrinol Metab Clin North Am 2010;39:641-54. 
4. Lerner SM. Kidney and pancreas transplantation in type 1 diabetes mellitus. Mt Sinai J Med 2008;75:372-84.

5. Anazawa T, Okajima H, Masui T, Uemoto S. Current state and future evolution of pancreatic islet transplantation. Ann Gastroenterol Surg 2018;3:34-42.

6. Bottino R, Knoll MF, Knoll CA, Bertera S, Trucco MM. The future of islet transplantation is now. Front Med (Lausanne) 2018;5:202.

7. Srinivasan P, Huang GC, Amiel SA, Heaton ND. Islet cell transplantation. Postgrad Med J 2007;83:224-9.

8. Ricordi C, Lacy PE, Scharp DW. Automated islet isolation from human pancreas. Diabetes 1989;38 Suppl 1:140-2.

9. Matsumoto S, Noguchi H, Naziruddin B, Onaca N, Jackson A, Nobuyo H, et al. Improvement of pancreatic islet cell isolation for transplantation. Proc (Bayl Univ Med Cent) 2007;20:357-62.

10. Gruessner AC. 2011 update on pancreas transplantation: comprehensive trend analysis of 25,000 cases followed up over the course of twenty-four years at the International Pancreas Transplant Registry (IPTR). Rev Diabet Stud 2011;8:6-16.

11. Rickels MR, Robertson RP. Pancreatic islet transplantation in humans: recent progress and future directions. Endocr Rev 2019;40:631-68.

12. Sutherland DE, Radosevich DM, Bellin MD, Hering BJ, Beilman GJ, Dunn TB, et al. Total pancreatectomy and islet autotransplantation for chronic pancreatitis. J Am Coll Surg 2012;214:409-24.

13. Ponte GM, Pileggi A, Messinger S, Alejandro A, Ichii H, Baidal DA, et al. Toward maximizing the success rates of human islet isolation: influence of donor and isolation factors. Cell Transplant 2007;16:595-607.

14. Ventura-Aguiar P, Ferrer-Fábrega J, José Ricart M. Pancreas transplantation. In: Tsoulfas G, editor. Organ donation and transplantation - current status and future challenges. London: IntechOpen, 2018:259-88.

15. Agarwal A, Brayman KL. Update on islet cell transplantation for type 1 diabetes. Semin Intervent Radiol 2012;29:908.

16. Ihm SH, Matsumoto I, Sawada T, Nakano M, Zhang HJ, Ansite JD, et al. Effect of donor age on function of isolated human islets. Diabetes 2006;55:1361-8.

17. Niclauss N, Bosco D, Morel P, Demuylder-Mischler S, Brault C, Milliat-Guittard L, et al. Influence of donor age on islet isolation and transplantation outcome. Transplantation 2011;91:360-6.

18. Nanji SA, Shapiro AM. Advances in pancreatic islet transplantation in humans. Diabetes Obes Metab 2006;8:15-25.

19. Lakey JR, Warnock GL, Rajotte RV, Suarez-Alamazor ME, Ao Z, Shapiro AM, et al. Variables in organ donors that affect the recovery of human islets of Langerhans. Transplantation 1996;61:1047-53.

20. Lakey JR, Rajotte RV, Warnock GL, Kneteman NM. Human pancreas preservation prior to islet isolation. Cold ischemic tolerance. Transplantation 1995;59:689-94.
21. Shapiro AM, Lakey JR, Ryan EA, Korbutt GS, Toth E, Warnock GL, et al. Islet transplantation in seven patients with type 1 diabetes mellitus using a glucocorticoid-free immunosuppressive regimen. N Engl J Med 2000;343:2308.

22. Hughes SJ, Clark A, McShane P, Contractor HH, Gray DW, Johnson PR. Characterisation of collagen VI within the islet-exocrine interface of the human pancreas: implications for clinical islet isolation? Transplantation 2006;81:423-6.

23. Shapiro AM. Islet transplantation in type 1 diabetes: ongoing challenges, refined procedures, and long-term outcome. Rev Diabet Stud 2012;9:385-406.

24. Markmann JF, Tomaszewski J, Posselt AM, Levy MM, Woehrle $\mathrm{M}$, et al. The effect of islet cell culture in vitro at 24 degrees $\mathrm{C}$ on graft survival and $\mathrm{MHC}$ antigen expression. Transplantation 1990;49:272-7.

25. Baidal DA, Froud T, Ferreira JV, Khan A, Alejandro R, Ricordi C. The bag method for islet cell infusion. Cell Transplant 2003;12:809-13.

26. Shapiro AM, Pokrywczynska M, Ricordi C. Clinical pancreatic islet transplantation. Nat Rev Endocrinol 2017;13:268-77.

27. Collaborative Islet Transplant Registry. Eighth annual report [Internet]. Collaborative Islet Transplant Registry; 2014 [cited 2020 Aug 17]. Available from: www.citregistry. org.

28. Shapiro AM, Ricordi C, Hering BJ, Auchincloss H, Lindblad R, Robertson RP, et al. International trial of the Edmonton protocol for islet transplantation. N Engl J Med 2006;355:1318-30.

29. Bellin MD, Barton FB, Heitman A, Harmon JV, Kandaswamy R, Balamurugan AN, et al. Potent induction immunotherapy promotes long-term insulin independence after islet transplantation in type 1 diabetes. Am J Transplant 2012;12:1576-83.

30. Berney T, Ferrari-Lacraz S, Bühler L, Oberholzer J, Marangon N, Philippe J, et al. Long-term insulinindependence after allogeneic islet transplantation for type 1 diabetes: over the 10-year mark. Am J Transplant 2009;9:419-23.

31. Hering BJ, Kandaswamy R, Ansite JD, Eckman PM, Nakano M, Sawada T, et al. Single-donor, marginal-dose islet transplantation in patients with type 1 diabetes. JAMA 2005;293:830-5.

32. Foster NC, Miller KM, Tamborlane WV, Bergenstal RM, Beck RW; T1D Exchange Clinic Network. Continuous glucose monitoring in patients with type 1 diabetes using insulin injections. Diabetes Care 2016;39:e81-2.

33. Hering BJ, Clarke WR, Bridges ND, Eggerman TL, Alejandro $\mathrm{R}$, Bellin MD, et al. Phase 3 trial of transplantation of human islets in type 1 diabetes complicated by severe hypoglycemia. Diabetes Care 2016;39:1230-40.

34. Bellin MD, Carlson AM, Kobayashi T, Gruessner AC, Hering BJ, Moran A, et al. Outcome after pancreatectomy and islet autotransplantation in a pediatric population. J Pediatr Gastroenterol Nutr 2008;47:37-44. 
35. Chinnakotla S, Bellin MD, Schwarzenberg SJ, Radosevich DM, Cook M, Dunn TB, et al. Total pancreatectomy and islet autotransplantation in children for chronic pancreatitis: indication, surgical techniques, postoperative management, and long-term outcomes. Ann Surg 2014;260:56-64.

36. Wahoff DC, Papalois BE, Najarian JS, Kendall DM, Farney AC, Leone JP, et al. Autologous islet transplantation to prevent diabetes after pancreatic resection. Ann Surg 1995;222:562-75

37. Zakrzewski W, Dobrzyński M, Szymonowicz M, Rybak Z. Stem cells: past, present, and future. Stem Cell Res Ther 2019;10:68.

38. Song S, Roy S. Progress and challenges in macroencapsulation approaches for type 1 diabetes (T1D) treatment: cells, biomaterials, and devices. Biotechnol Bioeng 2016;113: 1381-402.

39. Rother KI, Harlan DM. Challenges facing islet transplantation for the treatment of type 1 diabetes mellitus. J Clin Invest 2004;114:877-83.

40. Ryan EA, Paty BW, Senior PA, Bigam D, Alfadhli E, Kneteman NM, et al. Five-year follow-up after clinical islet transplantation. Diabetes 2005;54:2060-9.

41. Kenmochi T, Asano T, Maruyama M, Saigo K, Akutsu N, Iwashita C, et al. Clinical islet transplantation in Japan. J
Hepatobiliary Pancreat Surg 2009;16:124-30.

42. Johnston PC, Lin YK, Walsh RM, Bottino R, Stevens TK, Trucco M, et al. Factors associated with islet yield and insulin independence after total pancreatectomy and islet cell autotransplantation in patients with chronic pancreatitis utilizing off-site islet isolation: Cleveland Clinic experience. J Clin Endocrinol Metab 2015;100:1765-70.

43. Hering BJ, Clarke WR, Bridges ND, Eggerman TL, Alejandro $\mathrm{R}$, Bellin MD, et al. Phase 3 trial of transplantation of human islets in type 1 diabetes complicated by severe hypoglycemia. Diabetes Care 2016;39:1230-40.

44. Collaborative Islet Transplant Registry. Tenth annual report [Internet]. Collaborative Islet Transplant Registry; 2015 [cited 2021 Feb 19]. Available from: www.citregistry.org.

45. Bellin MD, Forlenza GP, Majumder K, Berger M, Freeman ML, Beilman GJ, et al. Total pancreatectomy with islet autotransplantation resolves pain in young children with severe chronic pancreatitis. J Pediatr Gastroenterol Nutr 2017;64:440-5.

46. Kirstie K. Danielson, Rebecca S. Monson, Li Y, Oberholzer J. 117-OR: Islet cell transplantation for type 1 diabetes: The UIC experience, 2004-2020. Diabetes 2020;69(Supplement $1)$. 